University of Nebraska - Lincoln

DigitalCommons@University of Nebraska - Lincoln

2013

How do Transfer Students Perform in Economics? Evidence from Intermediate Macroeconomics

Carlos J. Asarta

Scott M. Fuess Jr

Andrew Perumal

Follow this and additional works at: https://digitalcommons.unl.edu/econfacpub

This Article is brought to you for free and open access by the Economics Department at DigitalCommons@University of Nebraska - Lincoln. It has been accepted for inclusion in Economics Department Faculty Publications by an authorized administrator of DigitalCommons@University of Nebraska - Lincoln. 


\title{
RESEARCH IN ECONOMIC EDUCATION
}

\section{How do Transfer Students Perform in Economics? Evidence from Intermediate Macroeconomics}

\author{
Carlos J. Asarta, Scott M. Fuess, Jr., and Andrew Perumal
}

\begin{abstract}
For students taking intermediate-level economics, does it matter where they studied principles of economics? Does transferring college credit influence subsequent academic performance in economics? With a sample covering 1999-2008, the authors analyze in this article a group of nearly 1,000 students taking intermediate macroeconomics at a prominent state university. Despite seemingly impressivelooking grades from the principles of macroeconomics course, community college transfer students significantly underperformed their peers in the intermediate macroeconomics course, unlike transfer students from four-year institutions. Moreover, students who transferred other course work from community college (that is, other than the principles course) were relatively less likely to succeed in intermediate macroeconomics.
\end{abstract}

Keywords course selection and sequencing, transfer student performance, undergraduate economics

JEL codes A20, A22

Universities are receiving more course work transferred from outside institutions, especially community colleges. Some students begin their collegiate careers in community college and then transfer to four-year institutions. In other cases, students may matriculate at four-year institutions but search for transfer credit away from their "home" campuses. Such course "shopping" may be motivated by lower tuition costs or perceived convenience of community college offerings. Or it may be the case that four-year universities are under enrollment management pressure, and transfer credit represents a form of "outsourcing." 1 Whatever may motivate transfers, this trend raises the issue whether students with transfer credit are poised to succeed academically at their "home" four-year institutions. Focusing specifically on our own discipline, does transferring college credit influence subsequent academic performance in economics?

Carlos J. Asarta is an associate professor of practice at the University of Nebraska-Lincoln and corresponding author (e-mail: asarta@unl.edu). Scott M. Fuess, Jr. (e-mail: sfuess1@unl.edu) is Karl H. Nelson Professor of Economics and Department Chair at the University of Nebraska-Lincoln. Andrew Perumal (e-mail: andrew.perumal@umb.edu) is an assistant professor of economics at the University of Massachusetts, Boston. 
Research on economic education already has uncovered some results about transfer students. Studies by Borg, Mason, and Shapiro (1989) and Borg and Shapiro (1996) of students at the University of North Florida reported that performance in principles of economics was negatively influenced by transferring community college course work. However, consider a recent study by Elzinga and Melaugh (2009) of thousands of students—over a 20-year span — taking principles of microeconomics at the University of Virginia. Among their results, Elzinga and Melaugh found that those transferring credit from community colleges or from other four-year institutions did not perform significantly worse than other students in principles of microeconomics. ${ }^{2}$ What these studies did not consider is whether transferring credit in beginning economics affects performance in more advanced economics course work. ${ }^{3}$

In economics, the curriculum usually proceeds from introductory principles-level courses to intermediate theory classes and then to advanced course work in specific fields. Intermediate theory courses are often viewed with trepidation, for they tend to be much more abstract and detailed than principles classes. Consequently, intermediate-level courses serve as a type of gateway to advanced study in the discipline. For students taking intermediate-level economics at a four-year university, does it matter where they studied principles of economics? ${ }^{4}$

In this article, we analyze student performance in intermediate macroeconomics at a large state university in the Midwest. We were able to construct a rich data set of students who took this course over 1999-2008 from a single professor. The sample includes nearly 1,000 students. Controlling for student characteristics, academic credentials, and other factors, this study measures whether performance in intermediate macroeconomics is influenced by transferring credit from principles of macroeconomics.

\section{DATA AND SAMPLE}

\section{Background}

The university in this study is both a land grant and comprehensive public university, serving as "the flagship campus" of a statewide system. Undergraduate students can major in economics either from the business college (earning a BS degree) or the arts and sciences college (earning a BA degree).

The Department of Economics offers a three-credit course in intermediate macroeconomics that is a junior-level course in macroeconomic theory and provides foundation for advanced course work in economics. ${ }^{5}$ The course focuses on how economic aggregates are determined in a market-based economy (e.g., production, real income, employment, international trade and finance, inflation, and interest rates), the effects of monetary and fiscal policy, and economic growth.

Besides economics majors, the intermediate macro course serves other distinct constituencies on the university campus. Many finance students and actuarial science students take the course. It is common to find majors from mathematics and political science enrolling in the course. And, students majoring in agricultural economics and in agribusiness are required to take intermediate macroeconomics. Thus, in any given class there will be students representing various majors; in fact, noneconomics majors typically are in the majority.

Because the university is part of a statewide system, it accepts transfer credit from other campuses in the system. It also has articulation agreements to accept transfer credit from other 
institutions in the state, including community colleges. Indeed, one of the state's largest community colleges is in very close proximity to the university's campus.

\section{Data Description}

The data for this study are from 23 sections of intermediate macroeconomics taught by a single professor over 1999-2008. With the permission of the campus Institutional Review Board, we were able to obtain information from student records, including information about student characteristics (race, gender, age, residency status) and college entrance exam scores; grade information was available through computerized transcript records. For the intermediate course itself, we were able to obtain from the professor detailed information on student performance, specifically, outcomes for all graded exercises and final course grades. Our sample consists of 982 undergraduate students who earned a letter grade in the course, completed principles of macroeconomics, and for whom either SAT or ACT test scores were available. ${ }^{6}$

The professor routinely updated subject matter; nevertheless, a number of factors were steady over the sample period: pedagogical approach and classroom format (combination of lecture and discussion), types and rigor of reading materials assigned, educational technology (chalk board and overhead projector), grading instruments, and grading scale. ${ }^{7}$ The professor used four grading instruments. First, student attendance was recorded and graded. Second, there were thirteen weekly quizzes (essays/problem-solving format) used to compute a quiz average. ${ }^{8}$ Third, students were assigned to homework groups, and each group completed written homework assignments. ${ }^{9}$ Fourth, there was a comprehensive, written final exam (essays/problem-solving). Each of these instruments yielded a score in the interval [0-100]. Final grades were calculated by taking the weighted average of a student's (1) attendance score, (2) quiz average, (3) homework average, and (4) final exam score to compute a course-wide score in the [0-100] interval. ${ }^{10}$

To perform our analysis, we must make two data adjustments. Prior to the fall 2001 semester, letter grades at the university could have a "plus" designation but not a "minus" designation. Therefore, the range of possible grades was $A+, A, B+, B, C+, C, D+, D$, and $F$. During this period, the professor used the same grading scale: the $A$ range was $85-100$, with a score in the top quarter of the interval earning a "plus," the $B$ range was $75-85$, with a score in the top quarter of the interval earning a "plus," and so on.

From fall 2001 onward, letter grades could have either a "plus" or a "minus" designation, so grades of $A+, A, A-, \ldots, D+, D, D-$, and $F$ were possible. In this era, he used the following grading scale: the $A$ range was still $85-100$, with a score in the top (bottom) third of the interval earning a "plus" ("minus"), the $B$ range was still $75-85$, with a score in the top (bottom) third of the interval earning a "plus" ("minus"), and so on.

In our sample, there are 160 observations based on the old letter grade structure. We took the course-wide scores for these 160 students and applied the "plus/minus" grading scale of 2001 onward to generate adjusted letter grade observations. Thus, we have a consistent measure of student performance in intermediate macroeconomics over the entire sample period.

The second data adjustment involves college entrance examination scores. Prior to attending the university, the vast majority of students had completed the ACT aptitude test. In our sample, there are 24 students with SAT scores instead of ACT scores. We used the correspondence table developed by Dorans (1999) to transform the SAT observations into equivalent ACT scores. 


\section{Descriptive Statistics}

Focusing on characteristics of intermediate macroeconomics students, consider the descriptive statistics presented in table 1. Looking first at demographics, the students in the sample were predominantly male (77.8 percent), Caucasian (92.6 percent), and paid in-state tuition (90.8 percent). Only 21.3 percent of students were economics majors. Students exhibited a mean ACT

TABLE 1

Students in Intermediate Macroeconomics: Descriptive Statistics*

\begin{tabular}{|c|c|c|}
\hline Variable & Mean & Standard Deviation \\
\hline \multicolumn{3}{|l|}{ Demographic characteristics } \\
\hline Female & 0.222 & 0.416 \\
\hline Caucasian & 0.926 & 0.262 \\
\hline Out-of-state & 0.092 & 0.289 \\
\hline Age & 21.507 & 1.804 \\
\hline \multicolumn{3}{|l|}{ Academic characteristics } \\
\hline Econ major & 0.213 & 0.410 \\
\hline ACT math & 24.838 & 4.338 \\
\hline Univ GPA (entering the course) & 3.180 & 0.483 \\
\hline Credit hrs completed (entering the course) & 95.260 & 24.178 \\
\hline Credit hrs attempted (while taking the course) & 13.721 & 3.459 \\
\hline Junior & 0.391 & 0.488 \\
\hline Senior & 0.602 & 0.490 \\
\hline Summer & 0.123 & 0.329 \\
\hline Time since princ macro & 0.656 & 0.475 \\
\hline \multicolumn{3}{|l|}{ Grade measures } \\
\hline Princ macro & 3.019 & 0.805 \\
\hline Intermed macro & 2.605 & 0.923 \\
\hline \multicolumn{3}{|l|}{ Transfer student characteristics } \\
\hline Transfer princ macro from $C C$ & 0.095 & 0.293 \\
\hline Transfer princ macro from $4 \mathrm{yr}$ & 0.052 & 0.222 \\
\hline Transfer other (CC only) & 0.317 & 0.465 \\
\hline Transfer other (4 yr only) & 0.122 & 0.328 \\
\hline Transfer other (CC \& 4 yr $)$ & 0.095 & 0.293 \\
\hline \multicolumn{3}{|l|}{ Transferring princ macro } \\
\hline Transferred from $C C /$ started at $C C$ & 0.0540 & 0.2261 \\
\hline Transferred from CC/started at $4 \mathrm{yr}$ & 0.0153 & 0.1227 \\
\hline Transferred from CC/started at univ & 0.0306 & 0.1722 \\
\hline Transferred from $4 \mathrm{yr} /$ started at $C C$ & 0.0193 & 0.1378 \\
\hline Transferred from $4 \mathrm{yr} /$ started at $4 \mathrm{yr}$ & 0.0214 & 0.1447 \\
\hline Transferred from $4 \mathrm{yr} /$ started at univ & 0.0234 & 0.1513 \\
\hline \multicolumn{3}{|l|}{ Transfer students: credit hours transferred } \\
\hline Transfer princ macro from $C C$ & 50.513 & 27.439 \\
\hline Transfer princ macro from $4 y r$ & 54.588 & 26.300 \\
\hline Transfer other (CC only) & 15.827 & 20.594 \\
\hline Transfer other (4 yr only) & 15.216 & 15.709 \\
\hline Transfer other (CC \& 4 yr) & 28.678 & 22.073 \\
\hline
\end{tabular}

*Sample size: 982 students. 
mathematics score of 24.84. As they entered the intermediate course, their grade-point average for classes completed at the university exhibited a mean value of $3.18(A=4, F=0)$. On average, they achieved a grade of $B$ in principles of macroeconomics (mean score 3.02). In the intermediate course, they exhibited a mean grade of roughly $B-$ (mean score 2.61).

Student age was recorded in whole years (effective at the start of the course). The mean value for age is 21.5 years, suggesting that students took this course in their junior or senior year. Indeed, nearly all of the students enrolled either as seniors (60.2 percent) or juniors (39.1 percent). The average number of credit hours completed before taking the course was 95.3. With the semester course load averaging roughly 14 credit hours, the typical intermediate macro student was enrolled on a full-time basis. For most students (65.6 percent), more than twelve months elapsed between finishing the principles course and enrolling in the intermediate course.

When it comes to transferring economics credit, roughly one-seventh of intermediate macro students (14.7 percent) transferred credit to the university for the principles of macro course. Specifically, 9.5 percent of students transferred principles credit from community colleges, and another 5.2 percent transferred credit from four-year institutions.

Now take a closer look at those who transferred community college credit for the principles course. Whereas 5.4 percent of the sample consists of transferees who began their studies at community college, a similar share (4.6 percent) consists of community college transferees who began at the university or another four-year institution! Almost as many community college transferees started at a four-year school as started at community college. After enrolling at the university (or another four-year institution), apparently a number of students "shopped" at community colleges for credit in principles of macroeconomics.

Turning to those who transferred principles of macroeconomics from four-year institutions, notice that slightly more transferees started at the university than other four-year institutions. After entering the university, evidently some students "shopped" for credit at some other four-year school.

Besides those who transferred credit for principles of macroeconomics, another 53.4 percent of intermediate students transferred some other kind of course credit to the university prior to enrolling in intermediate macroeconomics, with 41.2 percent transferring community college credit. Only 314 of the 982 students in the sample-just 32.0 percent-had done all of their course work at the university.

Now look from another perspective at those who transferred credit for the principles course. As shown in table 1, if they transferred from community college they brought an average of 50.5 credit hours; if they transferred from a four-year institution the average is 54.6 credit hours. Therefore, students transferring principles of macroeconomics tended to move 50-55 credit hours of collegiate work, or nearly two years of college credit. Evidently they are "wholesale" transferees, enrolling at the university to finish the last two years of their baccalaureate studies.

In contrast, consider students who transferred some college credit but not for principles of macroeconomics. On average, transfers from community college averaged 15.8 credit hours, and those from four-year institutions averaged 15.2 credit hours. Among these students, there was a tendency to transfer only 15 credit hours of course work, or just one semester of college credit. Evidently these "incidental" transferees were concentrating their collegiate studies at the university. However, among those who transferred credit from both two- and four-year institutions, the mean for credit hours transferred is 28.7 , or roughly two semesters of collegiate work, putting them somewhere in between the wholesale and incidental transferees. 
TABLE 2

Difference between Students in Intermediate Macroeconomics

\begin{tabular}{|c|c|c|c|}
\hline Variable & $\begin{array}{c}\text { Transfer princ } \\
\text { macro }(n=144)\end{array}$ & $\begin{array}{l}\text { Princ macro at } \\
\text { Univ }(n=838)\end{array}$ & Difference \\
\hline \multicolumn{4}{|l|}{ Demographic characteristics } \\
\hline Female & 0.229 & 0.221 & 0.008 \\
\hline Caucasian & 0.889 & 0.932 & -0.043 \\
\hline Out-of-state & 0.104 & 0.089 & 0.015 \\
\hline \multicolumn{4}{|l|}{ Academic characteristics } \\
\hline Econ major & 18.056 & 21.838 & 3.782 \\
\hline ACT math & 22.965 & 25.160 & $-2.195^{* *}$ \\
\hline Univ GPA (entering the course) & 3.030 & 3.206 & $-0.176^{* *}$ \\
\hline Credit hrs completed (entering the course) & 102.762 & 93.971 & $8.791^{* *}$ \\
\hline Credit hrs attempted (while taking the course) & 13.535 & 13.753 & -0.218 \\
\hline Senior & 0.743 & 0.578 & $0.165^{* *}$ \\
\hline Summer & 0.153 & 0.118 & 0.035 \\
\hline \multicolumn{4}{|l|}{ Grade measures } \\
\hline Princ macro & 3.173 & 2.992 & $0.181^{*}$ \\
\hline Intermed macro & 2.348 & 2.649 & $-0.301^{* *}$ \\
\hline
\end{tabular}

${ }^{*} p<.05 ;{ }^{* *} p<.01$

\section{Differences between Students}

In our sample, 144 of 982 intermediate macroeconomics students transferred credit for the principles of macro course. table 2 presents test results for differences in means between the transferees and those who took the principles course at the university. Between the two groups, there is similarity in the proportion of female, Caucasian, out-of-state, and summertime students, as well as economics majors; differences in means are not statistically significant. Moreover, both groups tended to take the intermediate macroeconomics course while enrolled on a full-time basis.

In other respects, there are significant differences between the two groups of students. Transferees were older than nontransfer students and entered the intermediate course with more credit hours than their nontransfer counterparts. Transferees were much more likely than nontransferees to take intermediate macroeconomics as seniors ( 74.3 percent versus 57.8 percent) and to take the intermediate course more than twelve months after completing the principles course.

The aptitude credentials of nontransfer students are significantly better than for transferees. Nontransfer students exhibit a significantly higher mean ACT mathematics score than transfer students (25.16 compared to 22.97). At enrollment time in the intermediate course, nontransfer students also exhibit significantly better performance at the university (mean GPA of 3.21 versus 3.03).

Now turn to the matter of course grades. For principles of macroeconomics, transferees exhibit significantly higher grades on average than nontransfer students, 3.17 compared to 2.99. In contrast, for the intermediate course, transfer students exhibit significantly lower grades on average than nontransfer students, 2.35 versus 2.65 , roughly one-third of a letter grade. Despite 
seemingly impressive-looking grades in principles, transferees exhibit lower grades on average in intermediate macroeconomics.

\section{ESTIMATING GRADES IN INTERMEDIATE MACROECONOMICS: METHOD}

In our empirical analysis, the dependent variable of interest is a student's letter grade in intermediate macroeconomics. Given the discrete nature of this dependent variable, we followed Elzinga and Melaugh (2009) and Yang and Raehsler (2005) and used an ordered probit regression model.

Suppose the underlying relationship of interest can be characterized as

$$
Y^{*}=X \beta+\varepsilon,
$$

where $Y^{*}$ is a latent dependent variable (e.g., the exact level of learning by a student), $X$ is a matrix of explanatory variables, $\beta$ is a vector of parameters to be estimated, and $\varepsilon$ is a vector of normally distributed error terms. Exact observations of student learning are unavailable. Student performance, however, can be categorized, which implies the following:

$$
\begin{aligned}
& Y=0(\text { grade }: F) \text { if } Y^{*} \leq 0 \\
& Y=1(\text { grade }: D-) \text { if } 0<Y^{*} \leq \mu_{1} \\
& Y=2(\text { grade }: D) \text { if } \mu_{1}<Y^{*} \leq \mu_{2} \\
& Y=3(\text { grade }: D+) \text { if } \mu_{2}<Y^{*} \leq \mu_{3} \\
& \cdots \\
& Y=10(\text { grade: } A-) \text { if } \mu_{9}<Y^{*} \leq \mu_{10} \\
& Y=11(\text { grade: } A / A+) \text { if } \mu_{10}<Y^{*},
\end{aligned}
$$

where $\mu_{1}, \ldots, \mu_{10}$ are threshold variables in the probit model (which are determined as part of the maximum likelihood estimation procedure used in estimating the model). ${ }^{11}$

The ordered probit regression model uses student characteristics, academic credentials, timing of the intermediate course in the student's program, and course transfer information to explain student performance in intermediate macroeconomics as follows:

$$
\begin{aligned}
Y_{i}= & \beta_{0}+\beta_{1} \text { Female }_{i}+\beta_{2} \text { Non-Caucasian }_{i}+\beta_{3}{\text { Out-of }- \text { State }_{i}+\beta_{4} \text { Age }_{i}+\beta_{5} \text { Age }_{i}^{2}} \\
& +\beta_{6} \text { Econ Major }_{i}+\beta_{7} \text { ACT Math }_{i}+\beta_{8} \text { Univ GPA }_{i}+\beta_{9} \text { Credit Hrs Attempted }_{i} \\
& +\beta_{10} \text { Senior }_{i}+\beta_{11} \text { Summer }_{i}+\beta_{12} \text { Time Since Princ Macro }_{i} \\
& +\beta_{13} \text { Transfer Princ Macrofrom CC }_{i}+\beta_{14} \text { Transfer Princ Macrofrom } 4 \text { Yr }_{i} \\
& +\beta_{15} \text { Transfer Other }(\text { CC Only })_{i}+\beta_{16} \text { Transfer Other }(4 \text { Yr Only })_{i} \\
& +\beta_{17} \text { Transfer Other }(C C \& 4 \text { Yr })_{i}+\beta_{18} \text { Aca Yr 99-00 }{ }_{i}+\beta_{19} \text { Aca Yr 00-01 } \\
& +\cdots+\beta_{27} \text { Aca Yr 08-09 }+\varepsilon_{i},
\end{aligned}
$$

where $Y_{i}$ is the final grade earned by student $i$ in intermediate macroeconomics. 
The demographic variables include $\mathrm{Age}$ and $\mathrm{Age} \mathrm{e}^{2}$. They also include the following $0-1$ indicator variables: Female (=1 for female students), Non-Caucasian (= 1 if student is other than Caucasian), and Out-of-State ( $=1$ if student pays out-of-state tuition).

As discussed above, the majority of students enrolling in intermediate macroeconomics are not economics majors, with many concentrating in fields like agricultural economics, agribusiness, actuarial science, finance, and other social sciences. To see if there is any systematic difference in performance between economics majors and nonmajors, we also included the $0-1$ control variable Econ Major (= 1 if student's major includes economics).

To control for students' academic credentials, we included controls for mathematical aptitude and for student achievement at the university prior to taking the intermediate course. As a gauge of mathematical aptitude, we used the student's ACT mathematics score, ACT Math. As a measure of what students had achieved at the university, we used the student's grade-point average for courses completed at the university upon entering the intermediate course, Univ GPA. ${ }^{12}$ Presumably, better academic credentials mean better student performance in intermediate macroeconomics.

Students taking intermediate macroeconomics while enrolled on a full-time basis might have performed differently in the course than part-time students. To control for this possibility, we used Credit Hrs Attempted as an explanatory variable.

Grades in intermediate macroeconomics might be affected by some issues related to when the course was taken. The course is intended as a junior-level course in macroeconomic theory and is regarded by the economics faculty as a gateway to more advanced study in the discipline. Yet as discussed above, many students enrolled in the course during their senior year. Thus, we included Senior as an indicator variable ( $=1$ if course taken as a senior). If postponing until the senior year has an adverse (favorable) impact on student performance in the course, the Senior coefficient would be negative (positive).

Other things equal, the longer is the time span between completing the principles course and taking the intermediate course in macroeconomics, the greater is the possibility that knowledge will decay. Therefore, we also tracked time between the principles and intermediate courses with the 0-1 variable Time Since Princ Macro (= 1 if at least twelve months passed between completing the principles course and beginning the intermediate course), hypothesizing that performance in the intermediate class is inversely related to the time gap.

In another timing issue, the professor in this study regularly taught intermediate macroeconomics during the academic year (15-week semester) and sometimes during sessions of summer school (5-week session in June/early July). In the summertime, he maintained the same pedagogical approach and used the same grading instruments and standards as in the regular academic year; yet it may be the case that other things equal, summertime students performed differently than those taking the course during the regular academic year. Therefore, we also included the $0-1$ variable Summer (= 1 if course taken during a summer session) as an explanatory variable. $^{13}$

The key focus of our study was whether it matters where intermediate students took principles of macroeconomics. For someone who transferred principles credit from community college, we created the 0-1 indicator variable, Transfer Princ Macro from $C C$ (=1 for transfer credit). If those who transferred principles credit from community college performed relatively worse in the intermediate class, other things equal, the coefficient on this transfer variable would be negative. For someone who transferred principles credit from a four-year institution, we created the $0-1$ variable Transfer Princ Macro from $4 Y r$ (= 1 for transfer credit). If those who transferred 
principles credit from a four-year school performed relatively worse, the coefficient on this particular transfer variable would be negative.

Consider now a related transfer question. Does it matter if intermediate students transferred other college credit besides principles of macroeconomics? For someone who transferred collegiate credit besides the principles course, we created three different indicator variables: Transfer Other (CC Only) (= 1 if transferring credit only from community college), Transfer Other (4 $\mathrm{Yr}$ Only) (= 1 if transferring credit only from four-year institution), and Transfer Other (CC \& 4 $Y r)$ (= 1 if transferring credit from both two- and four-year institutions). Therefore, for students who transferred college credit besides principles of macroeconomics, if they performed worse in the intermediate course than nontransfer students, we would observe a negative coefficient on the pertinent transfer variable.

Finally, to track whether student performance has exhibited any trend over time, we included academic year dummy variables, using 1998-99 as the basis of comparison.

Our model does not specify controls for instructor effects or pedagogical changes. As explained above, the classes examined in this research were taught by the same faculty member using a similar pedagogical approach and similar grading instruments and standards. We acknowledge that our analysis cannot rule out potential self-selection as students may have chosen to take the course with this professor (or not). We cannot estimate a separate selection model because the data available are related only to one specific instructor.

When the professor taught intermediate macroeconomics during the regular academic year, he taught one of two sections scheduled per semester, and the other section was taught either by a faculty colleague (an occasional occurrence) or by a senior graduate student (the norm), with the graduate student instructor having served previously as the professor's teaching assistant in the course. For fall 2005 onward, his teaching load was reduced: He taught one section of intermediate macroeconomics in the fall semester only, and during the spring semester, the two sections scheduled were taught (a) by a faculty colleague and a senior graduate student or (b) by two senior graduate students. Whenever he taught the course in the summertime, his was the only section of the course offered. Therefore, considering the continuity in course structure, the paucity of alternative instructors, and that the course is a required one for most of the students enrolled in it, we believe our control measures are sufficient to argue that any data variation is due to student differences, not teacher or course-structure variation.

Using the method of maximum likelihood, estimates of the ordered probit are presented below. From the parameter and threshold estimates, it is possible to calculate the probability of receiving a particular grade in the course. Specifically, given the cumulative normal function $\Phi(\cdot)$, the probabilities are as follows:

$$
\begin{aligned}
& \text { Prob. }(Y=0 \text {; grade }: F)=\Phi(-X \mathrm{~b}) \\
& \text { Prob. }(Y=1 \text {; grade: } \mathrm{D}-)=\Phi\left(\mu_{1}-X \mathrm{~b}\right)-\Phi(-X \mathrm{~b}) \\
& \text { Prob. }(Y=2 \text {; grade: } D)=\Phi\left(\mu_{2}-X \mathrm{~b}\right)-\Phi\left(\mu_{1}-X \mathrm{~b}\right) \\
& \text { Prob. }(Y=3 \text {; grade: } D+)=\Phi\left(\mu_{3}-X \mathrm{~b}\right)-\Phi\left(\mu_{2}-X \mathrm{~b}\right) \\
& \ldots \\
& \text { Prob. }(Y=10 \text {; grade }: A-)=\Phi\left(\mu_{10}-X \mathrm{~b}\right)-\Phi\left(\mu_{9}-X \mathrm{~b}\right) \\
& \text { Prob. }(\mathrm{Y}=11 \text {; grade: } A / A+)=1-\Phi\left(\mu_{10}-X \mathrm{~b}\right),
\end{aligned}
$$

where the b's are the estimated coefficients and the $\mu$ 's are the estimated threshold values. 


\section{ESTIMATING GRADES IN INTERMEDIATE MACROECONOMICS: RESULTS AND DISCUSSION}

\section{Ordered Probit Results}

We used equation (3) to estimate probit regression coefficients, which are presented in table 3. Before interpreting the coefficient estimates, a word on the academic year dummy variables. For some years, other things equal, student performance was superior/inferior relative to the base year (1998-99); for other years, performance was not significantly different. ${ }^{14}$

Focusing on demographic characteristics, none of the estimated coefficients is statistically significant. Other things equal, grades in intermediate macroeconomics are unrelated to demographic characteristics such as gender, race, age, or out-of-state status. ${ }^{15}$ Further, grades in intermediate macroeconomics are also unrelated to the number of credit hours attempted while taking the course. ${ }^{16}$ Taking the course in the summertime instead of the regular academic year made no difference.

Turning to academic credentials, significantly positive coefficients indicate that course grades are directly related to ACT Math and Univ GPA. As expected, a stronger academic background is associated with earning higher grades in intermediate macroeconomics. ${ }^{17}$ The significantly positive coefficient on Econ Major shows that economics students earned higher grades in the course than nonmajors. Controlling for other factors, taking this junior-level course as a senior meant noticeably poorer course performance.

The key issue in this article is whether performance in the intermediate course depends on where students took the principles class. Looking at table 3, the coefficient on Transfer Princ Macro from $C C$ is significantly negative. Other things equal, those students who transferred principles credit from a community college underperformed in the intermediate course at the university. In contrast, transferring principles credit from a four-year institution did not matter, as illustrated by the insignificant coefficient on Transfer Princ Macro from $4 Y r^{18}$

Looking at transfer credit more broadly, the coefficient estimates for Transfer Other (CC Only) and Transfer Other ( $C C \& 4 \mathrm{Yr}$ ) are each negative and statistically significant. In contrast, the coefficient on Transfer Other ( $4 \mathrm{Yr}$ Only) is insignificant. Therefore, student performance in the intermediate macro course is unrelated to transferring credit from four-year institutions (i.e., credit besides principles of macroeconomics). Conversely, transferring other credit from community colleges is associated with significant underperformance in intermediate macroeconomics, as is transferring credit from a combination of two- and four-year institutions.

The findings can be summarized as follows. Transferring credit for the principles course from community college is associated with underperformance in intermediate macroeconomics. Further, transferring other course work from community college is also associated with underachievement in intermediate macroeconomics. In contrast, transferring credit for the principles course from a four-year institution does not matter, nor does transferring other course work from four-year schools. Whether or not transferees were "shopping" for course credit, whether they were transferring much or relatively little collegiate credit, the provenance of their course work matters. Students transferring credit from community college performed noticeably worse in the intermediate macro course than their peers; in contrast, students transferring credit from four-year institutions did not perform noticeably worse than their peers. 
TABLE 3

Ordered Probit Results: Predicting Intermediate Macroeconomics Grade

\begin{tabular}{|c|c|c|c|}
\hline Variable & Coefficient & Standard Error & $p$ \\
\hline \multicolumn{4}{|l|}{ Demographic characteristics } \\
\hline Female & 0.0535 & 0.0805 & 0.506 \\
\hline Non-Caucasian & 0.0083 & 0.1273 & 0.948 \\
\hline Out-of-state & -0.0571 & 0.1164 & 0.623 \\
\hline Age & 0.1169 & 0.1204 & 0.331 \\
\hline$A g e^{2}$ & -0.0015 & 0.0022 & 0.477 \\
\hline \multicolumn{4}{|l|}{ Academic characteristics } \\
\hline Econ major & $0.4952^{* *}$ & 0.0870 & 0 \\
\hline ACT math & $0.0297^{* *}$ & 0.0091 & 0.001 \\
\hline Univ GPA (entering the course) & $1.2834^{* *}$ & 0.0871 & 0 \\
\hline Credit hrs attempted (while taking the course) & -0.0061 & 0.0122 & 0.615 \\
\hline Senior & $-0.1830^{*}$ & 0.0874 & 0.036 \\
\hline Summer & -0.0323 & 0.1316 & 0.806 \\
\hline Time since princ macro & 0.1180 & 0.0853 & 0.166 \\
\hline \multicolumn{4}{|l|}{ Transfer characteristics } \\
\hline Transfer princ macro from $C C$ & $-0.2584^{*}$ & 0.1262 & 0.041 \\
\hline Transfer princ macro from $4 \mathrm{yr}$ & -0.2814 & 0.1567 & 0.073 \\
\hline Transfer other (CC only) & $-0.2184^{*}$ & 0.0857 & 0.011 \\
\hline Transfer other (4 yr only) & 0.0216 & 0.1119 & 0.847 \\
\hline Transfer other $(C C \& 4 y r)$ & $-0.2946^{*}$ & 0.1229 & 0.017 \\
\hline \multicolumn{4}{|l|}{ Academic year dummy variables } \\
\hline Aca yr 99-00 & 0.2603 & 0.2401 & 0.278 \\
\hline Aca yr $00-01$ & 0.3315 & 0.1788 & 0.064 \\
\hline Aca yr $01-02$ & 0.2771 & 0.1743 & 0.112 \\
\hline Aca yr $02-03$ & 0.0474 & 0.1702 & 0.781 \\
\hline Aca yr 03-04 & $0.6629^{* *}$ & 0.1721 & 0 \\
\hline Aca yr 04-05 & $0.5781^{* *}$ & 0.1757 & 0.001 \\
\hline Aca yr 05-06 & $-0.6300^{* *}$ & 0.2171 & 0.004 \\
\hline Aca yr 06-07 & $0.4196^{*}$ & 0.1977 & 0.034 \\
\hline Aca yr 07-08 & $0.4487^{*}$ & 0.1886 & 0.017 \\
\hline Aca yr 08-09 & 0.4269 & 0.2185 & 0.051 \\
\hline \multicolumn{4}{|l|}{ Threshold values } \\
\hline$\mu_{1}$ & $0.2481^{* *}$ & & \\
\hline$\mu_{2}$ & $0.4730^{* *}$ & & \\
\hline$\mu_{3}$ & $0.6924^{* *}$ & & \\
\hline$\mu_{4}$ & $0.9825^{* *}$ & & \\
\hline$\mu_{5}$ & $1.6555^{* *}$ & & \\
\hline$\mu_{6}$ & $2.0814^{* *}$ & & \\
\hline$\mu_{7}$ & $2.4932^{* *}$ & & \\
\hline$\mu_{8}$ & $2.9086^{* *}$ & & \\
\hline$\mu_{9}$ & $3.4675^{* *}$ & & \\
\hline$\mu_{10}$ & $4.2761^{* *}$ & & \\
\hline Constant & $-4.4866^{* *}$ & 1.7003 & 0.008 \\
\hline Pseudo $R^{2}$ & 0.1084 & & \\
\hline Log likelihood & -2002.49 & & \\
\hline Sample size & 982 & & \\
\hline
\end{tabular}

${ }^{*} p<.05 ;{ }^{* *} p<.01$ 
TABLE 4

Predicting the Probability of Obtaining a Particular Grade (Conditional on an "Average" Student)

\begin{tabular}{lcc}
\hline Grade & Grade distribution $(\%)$ & Predicted probability $(\%)$ \\
\hline$F$ & 3.213 & 1.037 \\
$D-$ & 1.947 & 0.911 \\
$D$ & 2.532 & 1.342 \\
$D+$ & 2.921 & 1.968 \\
$C-$ & 4.771 & 3.913 \\
$C$ & 16.358 & 16.379 \\
$C+$ & 13.242 & 15.303 \\
$B-$ & 12.269 & 16.306 \\
$B$ & 11.490 & 15.276 \\
$B+$ & 12.950 & 15.156 \\
$A-$ & 11.587 & 9.929 \\
$A / A+$ & 6.719 & 2.480 \\
\hline
\end{tabular}

To put the regression results in some perspective, we followed Elzinga and Melaugh (2009) and calculated the probability of an "average" student earning one of the possible letter grades (i.e., a hypothetical student exhibiting the mean value of each of the explanatory variables). In essence, we are comparing the distribution of grades as predicted by the model with the actual distribution, which illustrates goodness of fit. The results are presented in table 4 . The figures reported in the table confirm that our model approximates quite well the actual grade distribution (correlation coefficient: 0.955 ). According to prediction, a statistically average student is most likely to earn a grade of $C$, which is actually what happened.

As is well-known, in a probit model the regression coefficients do not yield the marginal effects of the explanatory variables. With the threshold values calculated by the probit model, $\mu_{\mathrm{i}}$, marginal effects of explanatory variables and their significance can be assessed (Greene 2002). Focusing on a statistically average student (i.e., inserting mean values for each of the explanatory variables), tables 5 and 6 report the marginal effects of explanatory variables on grades in intermediate macroeconomics. Table 5 focuses on marginal effects related to transfer issues. Table 6 focuses on other explanatory variables.

\section{Marginal Effects: Transfer Issues}

According to the figures reported in Table 5, transferring credit from community college has a negative impact on student performance in intermediate macroeconomics. Specifically, the following variables exhibit a significantly negative impact on a student's grade: Transfer Princ Macro from CC, Transfer Other (CC Only), and Transfer Other (CC \& $4 \mathrm{Yr}$ ).

For a statistically average student, Transfer Princ Macro from CC significantly lowers the probability of earning a relatively high course grade (i.e., a grade of $B$ or higher). Specifically, it lowers the probability of earning an $A / A+$ (by 2.6 percent) or an $A-$ (by 2.8 percent); likewise, it reduces the likelihood of earning a $B+$ (by 1.8 percent) or a $B$ (by 0.7 percent). Meanwhile, Transfer Princ Macro from $C C$ substantially increases the probability of earning a failing grade (by 1.6 percent) or mediocre grade like $C$ (by 2.3 percent) or $C$ - (by 1.1 percent). 
TABLE 5

Predicting Course Grade: Marginal Effects of Transfer Characteristics

\begin{tabular}{|c|c|c|c|c|c|c|}
\hline Grades & $F(\%)$ & $D-(\%)$ & $D(\%)$ & $D+(\%)$ & $C-(\%)$ & $C(\%)$ \\
\hline \multicolumn{7}{|l|}{ Transfer characteristics } \\
\hline Transfer princ macro from $C C$ & $1.6^{*}$ & 0.6 & 0.7 & 0.7 & $1.1^{*}$ & $2.3^{*}$ \\
\hline Transfer princ macro from $4 \mathrm{yr}$ & 1.8 & 0.7 & 0.7 & 0.8 & 1.1 & 2.5 \\
\hline Transfer other (CC only) & $1.4^{*}$ & $0.5^{*}$ & $0.6^{*}$ & $0.6^{*}$ & $0.9^{*}$ & $1.9^{*}$ \\
\hline Transfer other (4 yr only) & -0.1 & -0.1 & -0.1 & -0.1 & -0.1 & -0.2 \\
\hline Transfer other (CC \& 4 yr) & $1.8^{*}$ & $0.7^{*}$ & $0.8^{*}$ & $0.8^{*}$ & $1.2^{*}$ & $2.6^{*}$ \\
\hline Grades & $C+(\%)$ & $B-(\%)$ & $B(\%)$ & $B+(\%)$ & $A-(\%)$ & $A / A+(\%)$ \\
\hline \multicolumn{7}{|l|}{ Transfer characteristics } \\
\hline Transfer princ macro from $C C$ & $0.8^{*}$ & 0.1 & $-0.7^{*}$ & $-1.8^{*}$ & $-2.8^{*}$ & $-2.6^{*}$ \\
\hline Transfer princ macro from $4 y r$ & 0.9 & 0.1 & -0.8 & -1.9 & -3.1 & -2.8 \\
\hline Transfer other (CC only) & $0.7^{*}$ & 0.1 & $-0.6^{*}$ & $-1.5^{*}$ & $-2.4^{*}$ & $-2.2^{*}$ \\
\hline Transfer other (4 yr only) & -0.1 & 0 & 0.1 & 0.1 & 0.2 & 0.2 \\
\hline Transfer other (CC\& 4 yr $)$ & $1.0^{*}$ & 0.1 & $-0.8^{*}$ & $-2.0^{*}$ & $-3.2^{*}$ & $-2.9^{*}$ \\
\hline
\end{tabular}

${ }^{*} p<.05 ;{ }^{* *} p<.01$

To illustrate these findings, consider figure 1, which shows the distribution of grades in intermediate macroeconomics, distinguishing between students who transferred the principles course from community college and those who did not. Among the transferees, it is relatively rare to observe grades of $B+$ or higher, whereas such grades are much more common among the

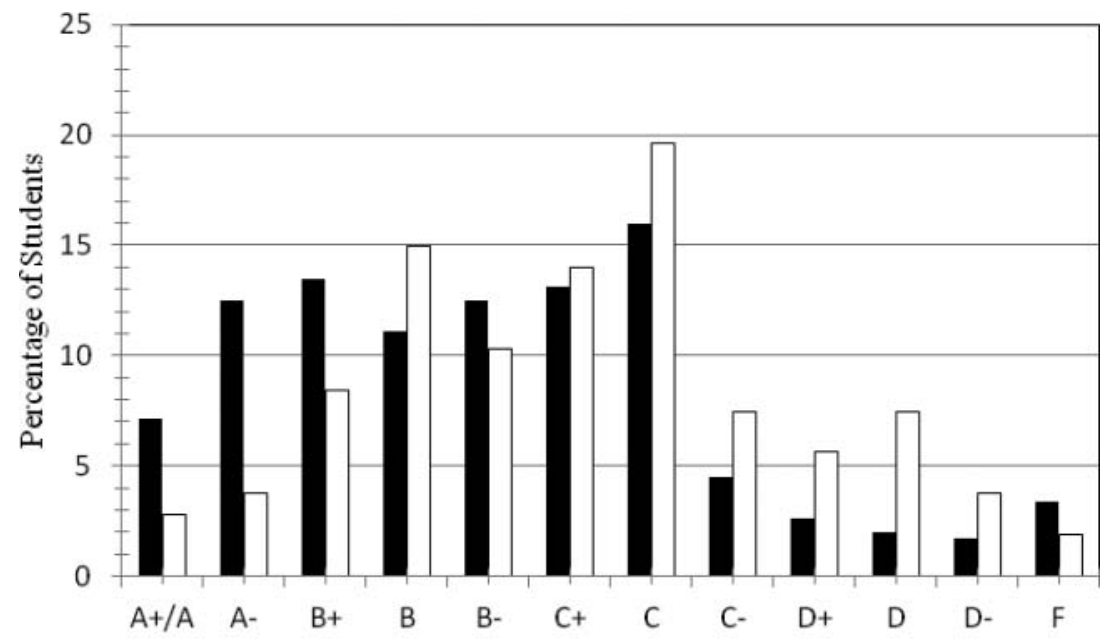

-Did not transfer P.Macro from CC $\square$ Transferred P.Macro from CC

FIGURE 1 Grade distribution in intermediate macroeconomics: Transferring principles of macroeconomics from a community college. 
TABLE 6

Predicting Course Grade: Marginal Effects of Other Characteristics

\begin{tabular}{|c|c|c|c|c|c|c|}
\hline Grades & $F(\%)$ & $D-(\%)$ & $D(\%)$ & $D+(\%)$ & $C-(\%)$ & $C(\%)$ \\
\hline \multicolumn{7}{|l|}{ Demographic characteristics } \\
\hline Female & -0.3 & -0.1 & -0.1 & -0.2 & -0.2 & -0.5 \\
\hline Non-Caucasian & -0.1 & 0 & 0 & 0 & 0 & -0.1 \\
\hline Out-of-state & 0.4 & 0.1 & 0.1 & 0.2 & 0.2 & 0.5 \\
\hline Age & -0.7 & -0.3 & -0.3 & -0.3 & -0.5 & -1.0 \\
\hline$A g e^{2}$ & 0 & 0 & 0 & 0 & 0 & 0 \\
\hline \multicolumn{7}{|l|}{ Academic characteristics } \\
\hline Econ major & $-3.1^{* *}$ & $-1.2^{* *}$ & $-1.3^{* *}$ & $-1.4^{* *}$ & $-2.0^{* *}$ & $-4.4^{* *}$ \\
\hline ACT math & $-0.2^{* *}$ & $-0.1^{* *}$ & $-0.1^{* *}$ & $-0.1^{* *}$ & $-0.1^{* *}$ & $-0.3^{* *}$ \\
\hline Univ GPA (entering the course) & $-8.0^{* *}$ & $-3.1^{* *}$ & $-3.3^{* *}$ & $-3.6^{* *}$ & $-5.2^{* *}$ & $-11.3^{* *}$ \\
\hline $\begin{array}{l}\text { Credit hrs attempted } \\
\quad \text { (while taking the course) }\end{array}$ & 0 & 0 & 0 & 0 & 0 & 0.1 \\
\hline Senior & $1.1^{*}$ & 0.4 & 0.5 & $0.5^{*}$ & $0.7^{*}$ & $1.6^{*}$ \\
\hline Summer & 0.2 & 0.1 & 0.1 & 0.1 & 0.1 & 0.3 \\
\hline Time since princ macro & -0.7 & -0.3 & -0.3 & -0.3 & -0.5 & -1.0 \\
\hline Grades & $C+(\%)$ & $B-(\%)$ & $B(\%)$ & $B+(\%)$ & $A-(\%)$ & $A / A+(\%)$ \\
\hline \multicolumn{7}{|l|}{ Demographic characteristics } \\
\hline Female & -0.2 & 0 & 0.1 & 0.4 & 0.6 & 0.5 \\
\hline Non-Caucasian & 0 & 0 & 0 & 0.1 & 0.1 & 0.1 \\
\hline Out-of-state & 0.2 & 0 & -0.2 & -0.4 & -0.6 & -0.6 \\
\hline Age & -0.4 & 0 & 0.3 & 0.8 & 1.3 & 1.2 \\
\hline$A g e^{2}$ & 0 & 0 & 0 & 0 & 0 & 0 \\
\hline \multicolumn{7}{|l|}{ Academic characteristics } \\
\hline Econ major & $-1.6^{* *}$ & -0.1 & $1.3^{* *}$ & $3.4^{* *}$ & $5.4^{* *}$ & $4.9^{* *}$ \\
\hline ACT math & $-0.1^{* *}$ & 0 & $0.1^{* *}$ & $0.2^{* *}$ & $0.3^{* *}$ & $0.3^{* *}$ \\
\hline Univ GPA (entering the course) & $-4.1^{* *}$ & -0.3 & $3.4^{* *}$ & $8.8^{* *}$ & $14.1^{* *}$ & $12.7^{* *}$ \\
\hline $\begin{array}{l}\text { Credit hrs attempted } \\
\quad \text { (while taking the course) }\end{array}$ & 0 & 0 & 0 & 0 & -0.1 & -0.1 \\
\hline Senior & $0.6^{*}$ & 0 & $-0.5^{*}$ & $-1.3^{*}$ & $-2.0^{*}$ & $-1.8^{*}$ \\
\hline Summer & 0.1 & 0 & -0.1 & -0.2 & -0.4 & -0.3 \\
\hline Time since princ macro & -0.4 & 0 & 0.3 & 0.8 & 1.3 & 1.2 \\
\hline
\end{tabular}

${ }^{*} p<.05 ;{ }^{* *} p<.01$

other students. Similarly, for community college transferees, $C$ s and $D$ s tend to be more common than for other students.

Aside from transferring the principles course from community college, transferring other course work from community college has a negative impact on grades in intermediate macroeconomics. As shown in table 5, for both Transfer Other (CC Only) and Transfer Other (CC \& 4 $Y r$ ), the likelihood of earning $B \mathrm{~s}$ or $A \mathrm{~s}$ in the intermediate course is substantially reduced while the likelihood of earning $C \mathrm{~s}, D \mathrm{~s}$, or $F$ is significantly increased. In contrast, transferring other credit from a four-year institution has no impact at all on the course performance.

To illustrate, figure 2 shows the grade distribution of intermediate macro students, distinguishing between those who transferred other credit (i.e., other than the principles course) from 


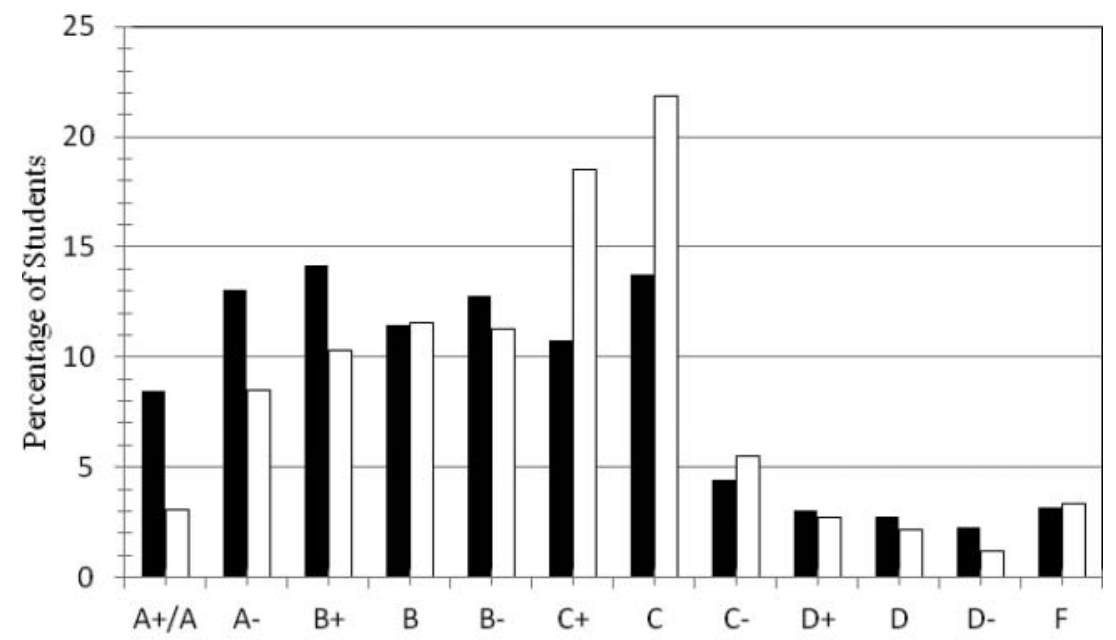

aDid not transfer courses from CC $\quad \square$ Transferred courses from CC

FIGURE 2 Grade distribution in intermediate macroeconomics: Transferring from a community college (other than principles of macroeconomics).

community college and those who did not. Among the transferees, it is comparatively rare to observe grades of $B+$ or higher, yet such grades are much more common among other students.

\section{Other Marginal Effects}

Not only does transferring credit from community college adversely influence academic performance in intermediate macroeconomics, so does taking this course in the senior year. As shown in table 6, for a statistically average student, Senior significantly lowers the probability of earning a grade of $B$ or higher while increasing the likelihood of a failing grade or mediocre one like $D+, C-$, or $C$. In other words, taking this junior-level course as a senior tends to shift student performance from the upper grades to mediocrity or failure.

Other significant marginal effects are associated with the academic background of students. Perhaps not surprisingly, economics majors significantly outperform other students in intermediate macroeconomics. Being an economics major significantly increases the probability of earning $A \mathrm{~s}$ or $B \mathrm{~s}$, reducing the likelihood of receiving a $C+$ or worse. As expected, a small improvement in either ACT Math or Univ GPA significantly shifts the likelihood in favor of a relatively high grade ( $B$ or better), away from earning a mediocre or failing grade. These findings underscore the importance of key academic factors in determining success in intermediate macroeconomics: familiarity with the discipline of economics, mathematical aptitude (represented by ACT Math), and overall academic aptitude (represented by Univ GPA). 


\section{SUMMARY AND CONCLUSION}

In this study, we found that while transfer students exhibited significantly higher course grades in principles of macroeconomics than nontransferees, transferring the principles course from community college has a negative and significant impact on performance in the intermediate macroeconomics course. For students exhibiting average characteristics, community college transferees were much less likely than nontransferees to earn grades of $B$ or better and much more likely to earn a failing or mediocre grade. Further, transferring other course work from community college (i.e., classes besides principles of macroeconomics) has a negative impact on grades in intermediate macroeconomics. In contrast, transferring credit from a four-year institution-either for the principles of macroeconomics or other classes-is not associated with underachievement in the intermediate course. These findings may give pause to university administrators as they consider course transfer policies. Transferring may allow students access to a university, but what about success at the university?

When it comes to studying a challenging social science like economics beyond the introductory level, transferees from community college have struggled. Some students in our sample are "wholesale" transferees, transferring close to two years of college credit, while others are "incidental" transferees, transferring about a semester of college credit. Moreover, some transferees evidently are "shopping," looking elsewhere for collegiate credit after matriculating at the university. Wholesale transferee or not, shopping around for collegiate credit or not, what seems to matter is the provenance of transfer credit. Students transferring community college credit were relatively less likely than their peers to succeed in junior-level intermediate macroeconomics. Contrarily, students transferring credit from four-year institutions did not lag noticeably behind their peers in the intermediate course.

Our findings uncover another matter of concern. Those who took junior-level intermediate macroeconomics in their senior year lagged significantly behind other students in the course. Inquiries on our part suggest that students have not been delayed by enrollment bottlenecks, so many students appear to be postponing this course. But if the course is a gateway to more advanced study in the field, does this postponement have adverse consequences? While this question may be one for further study, it would seem at the very least that there is a need to reconsider how students are advised.

\section{NOTES}

1. For discussion of transfer issues and citations, see Hossler and Hoezee $(2004,2006)$. On community college enrollment trends, see Jaschik (2009), LeBard (1999), Moltz (2009), and Provasnik and Planty (2008).

2. A similar finding is reported by Arias and Walker (2004), who studied a smaller sample of students from Georgia College \& State University.

3. A study of Clemson University students by Dills and Hernández-Julián (2008) examined the impact of transferring an introductory-level course on performance in an intermediate-level course. Their analysis, however, aggregated across disciplines and did not focus specifically on the discipline of economics. 
4. In a study of 2,000 Florida State University students over the 1981-93 period, Laband and Piette (1995) examined whether transferring principles credit affected performance in "upper-level" economics courses (i.e., both intermediate theory courses and advanced-level courses). Thus, their analysis does not distinguish whether transferring principles credit affects performance at the next level of study (i.e., intermediate economic theory).

5. Prerequisites for this course are (1) principles of macroeconomics, (2) principles of microeconomics, (3) introductory statistics, and (4) introductory calculus. The principles courses are not required to be taken in a particular order.

6. It has been suggested that transfer students could be less likely to complete the course and earn a grade, which means any transfer effect might be understated. To address this possibility, we examined the student records to identify every student who withdrew from the course, a total of 80 students. Of the 80 students who dropped, 60 had not transferred credit for principles of macroeconomics. Given that the number of course droppers is only 8 percent of the number of students who completed the course, and that only one-fourth of those course droppers were transfer students, we are confident that our estimates do not substantially underestimate the transfer effect.

7. Specifically, the data begin with the spring semester of the 1998-99 academic year (spring 1999) and continue through the fall semester of the 2008-9 academic year (fall 2008). Prior to spring 1999, the professor used different grading instruments so there would be a break in continuity if the sample began earlier than spring 1999.

8. A student's lowest quiz score was omitted.

9. When teaching the course during a summer session, the professor maintained a similar pedagogical approach and used the same grading instruments. There was one difference in the summertime regarding homework assignments: Students worked on their written assignments individually, not in homework groups.

10. Throughout the 1999-2008 sample period, course grades were based on a weighted average of (1) attendance, (2) quiz average, (3) homework average, and (4) final exam score. Over the sample period, the professor did make some minor adjustments to the weights attached to these grading instruments. At first, the respective grading weights were 10 percent, 30 percent, 25 percent, and 35 percent. In fall 2002 , he shifted some weight from the homework assignments to the final exam, with the respective weights becoming 10 percent, 30 percent, 20 percent, and 40 percent. In fall 2003, he shifted some weight from the attendance score to the quiz average, so the respective grading weights were 5 percent, 35 percent, 20 percent, and 40 percent. In fall 2007, he shifted even more weight from the homework average to the quiz average, making the respective grading weights as follows: 5 percent, 40 percent, 15 percent, and 40 percent. Therefore, it was always the case that a student's course grade depended overwhelmingly on the quizzes and final exam.

11. Students earning a grade of $A$ at the university earn a score of 4.0 for their grade-point average, as do students earning a grade of $A+$. Because $A$ and $A+$ have the same consequences for a student's grade-point average, we combined $A$ and $A+$.

12. It has been argued that the use of a single variable to proxy for student ability, like GPA, tends to result in very large differences in the estimates of learning gains (see Grove, Wasserman, and Grodner 2006). Further, Univ GPA may be influenced by grading rigor in the academic major (see Yang and Raehsler 2005). Thus, we also included ACT Math, which reflects a key aptitude prior to college entrance and is independent of variability in GPA.

13. As shown in table 1,12.3 percent of the students in the sample took the course in the summertime.

14. We performed a likelihood ratio test to determine the joint significance of including the academic year variables as controls, obtaining a $\chi^{2}$-statistic of 78.08 , which supports inclusion of these dummy variables in the specification.

15. Some researchers have reported a gender gap, with males outperforming females (e.g., Bolch and Fels 1974; Siegfried 1979; Williams, Waldauer, and Duggal 1992). More recent studies, however, have found no gender gap across the economics curriculum or on tests of economic knowledge (see Swope and Schmitt 2006; Ziegert 2000).

16. The insignificant impact of credit hours attempted is consistent with a finding by Hasnat and Didia (1996), who analyzed the performance of transfer students in an economics statistics course at the State University of New York, College at Brockport. 
17. This finding is consistent with past research in economic education (e.g., Ballard and Johnson 2004; Barr and Carr 1980; Becker 1997; Wetzel, O’Toole, and Millner 1991; and Yang and Raehsler 2005).

18. It has been suggested that transferring credit for principles of microeconomics might affect performance in intermediate macroeconomics, yet we did not find evidence of a significant association.

\section{REFERENCES}

Arias, J. J., and D. M. Walker. 2004. Additional evidence on the relationship between class size and student performance. Journal of Economic Education 35: 311-29.

Ballard, C. L., and M. F. Johnson. 2004. Basic math skills and performance in an introductory economics class. Journal of Economic Education 35: 3-23.

Barr, S. Z., and G. D. Carr. 1980. Improving economic understanding in junior college economics principles courses. Community/Junior Research Quarterly 4(3): 219-24.

Becker, W. E. 1997. Teaching economics to undergraduates. Journal of Economic Literature 35(2): 1347-73.

Bolch, B. W., and R. Fels. 1974. A note on sex and economic education. Journal of Economic Education 6: 64-67.

Borg, M. O., P. M. Mason, and S. L. Shapiro. 1989. The case of effort variables in student performance. Journal of Economic Education 20: 309-13.

Borg, M. O., and S. L. Shapiro. 1996. Personality type and student performance in principles of economics. Journal of Economic Education 27: 3-25.

Dills, A. K., and R. Hernández-Julián. 2008. Transfer college quality and student performance. Eastern Economic Journal 34(2): 172-89.

Dorans, N. J. 1999. Correspondences between ACT and SAT I scores. College Board Research Report 99-1; ETS Research Report 99-2. New York: The College Board.

Elzinga, K. G., and D. O. Melaugh. 2009. 35,000 principles of economics students: Some lessons learned. Southern Economic Journal 76(1): 32-46.

Greene, W. H. 2002. Econometric analysis. 5th ed. Upper Saddle River, NJ: Prentice Hall.

Grove, W. A., T. Wasserman, and A. Grodner. 2006. Choosing a proxy for academic aptitude. Journal of Economic Education 37: 131-47.

Hasnat, B., and D. Didia. 1996. Determinants of performance in an economics statistics course: Are transfer students at any disadvantage? New York Economic Review 27(Fall): 60-72.

Hossler, D. (ed.), and L. Hoezee (assoc. ed.). 2004. The Enrollment Management Review 19(2). http://www.collegeboard. com/prod_downloads/highered/nn/emr_w2004.pdf (accessed March 29, 2010).

- 2006. The Enrollment Management Review 21(4). http://www.collegeboard.com/prod_downloads/highered/pub/ emr/EMR_Summer_2006.pdf (accessed March 29, 2010).

Jaschik, S. 2009. Community college surge. Inside Higher Ed, March 18. http://www.insidehighered.com/news/2009/03/ 18/league (accessed March 29, 2010).

Laband, D. N., and M. J. Piette. 1995. Does who teaches principles of economics matter? American Economic Review Papers and Proceedings 85(2): 335-38.

LeBard, C. 1999. Reverse transfers in the community college. Eric Digest. ERIC Identifier: ED433871. http://www. ericdigests.org/2000-2/reverse.htm (accessed March 29, 2010).

Moltz, D. 2009. Why reverse transfer? Inside Higher Ed, April 17. http://www.insidehighered.com.layout/set/print/news/ 2009/04/17/transfer (accessed March 29, 2010).

Provasnik, S., and M. Planty. 2008. Community college: Special supplement to the condition of education 2008 (NCES 2008-003). Washington, DC: National Center for Education Statistics, Institute of Education Sciences, U.S. Department of Education.

Siegfried, J. J. 1979. Male-female differences in economic education: A survey. Journal of Economic Education 10: $1-11$.

Swope, K. J., and P. M. Schmitt. 2006. The performance of economic graduates over the entire curriculum: The determinants of success. Journal of Economic Education 37: 387-94. 
Wetzel, J. N., D. M. O’Toole, and E. L. Millner. 1991. A qualitative response model of student performance on a standardized test. Atlantic Economic Journal 19(3): 8-25.

Williams, M. L., C. Waldauer, and V. G. Duggal. 1992. Gender differences in economic knowledge: An extension of the analysis. Journal of Economic Education 23: 219-31.

Yang, C. W., and R. D. Raehsler. 2005. An economic analysis on intermediate microeconomics: An ordered probit model. Journal for Economics Educators 5(3): 1-11.

Ziegert, A. L. 2000. The role of personality temperament and student learning in principles of economics. Journal of Economic Education 31: 307-22. 